Bryant University

Bryant Digital Repository

History and Social Sciences Faculty Journal

Articles

History and Social Sciences Faculty

Publications and Research

Summer 2006

\title{
U.S. Human Rights Policy in the Post-Cold War Era
}

John W. Dietrich

Bryant University

Follow this and additional works at: https://digitalcommons.bryant.edu/histss_jou

\section{Recommended Citation}

Dietrich, John W., "U.S. Human Rights Policy in the Post-Cold War Era" (2006). History and Social Sciences Faculty Journal Articles. Paper 78.

https://digitalcommons.bryant.edu/histss_jou/78

This Article is brought to you for free and open access by the History and Social Sciences Faculty Publications and Research at Bryant Digital Repository. It has been accepted for inclusion in History and Social Sciences Faculty Journal Articles by an authorized administrator of Bryant Digital Repository. For more information, please contact dcommons@bryant.edu. 


\section{U.S. Human Rights Policy in the Post-Cold War Era: \\ $\underline{\text { Continued Structural Constraints }}$ \\ $\underline{\text { Across Time and Administrations }}$}

John W. Dietrich

Bryant University 
Historically, the implementation of U.S. human rights policy has been a case of "two steps forward, one step back." From its earliest days, the United States has attempted, at least to some degree, to include morality, the protection of individual rights, and the spread of democracy in foreign policy calculations. These efforts became more prominent after World War II. By the late-1980s, human rights concerns were firmly embedded in U.S. foreign policy rhetoric, policy-making institutions, and global actions. Despite these long-term trends, full policy implementation of human rights principles was constrained over time by lack of U.S. power, U.S. wariness of multilateral institutions and international legal commitments, competing policy priorities, and the limited institutional power of U.S. human rights advocates. The end of the Cold War and other contemporaneous international and domestic shifts appeared to finally remove these long-standing limitations. Now, a little more than a decade later, it is clear that human rights considerations have shaped recent policies in many ways. Strikingly, though, past limitations have persisted. The continuing existence of these limits shows that they were never short-term, era specific problems, but rather deeper constraints that stem from the realities of global and domestic politics. Thus, while human rights considerations have become an important component of policy, those expecting a dominant role for human rights in U.S. foreign policy will always be disappointed and may fail to appreciate the progress that does occur.

\section{HISTORIC TRENDS}

Massachusetts Bay Governor John Winthrop stated in 1630, "we shall be as a City upon a Hill, the eyes of all people are upon us." This early expression of American exceptionalism and moralism was followed by many similar statements from early American leaders. ${ }^{2}$ These views led some to promote "crusading interventionism" to spread liberty; others were led to advocate "complacent withdrawal from world affairs" to keep America free from the world's impurities. ${ }^{3}$ Either way, human rights ideas had some impact on early policy-makers. Those ideas and the crusading internationalist viewpoint gained new prominence after World War II. The United States rose to superpower status and worked with other countries and the United Nations to 
establish new global human rights standards. ${ }^{4}$ In the 1970s, Congress and President Carter placed even more focus on human rights and took steps to create the legislative and institutional framework that still guides U.S. human rights policy today. ${ }^{5}$ In the 1980 s, under President Reagan, significant changes in human rights policy occurred, but the underlying focus remained. ${ }^{6}$

At the same time as these positive developments, full implementation of human rights principles was constrained by various factors. The limitations included an early lack of power that restricted the U.S. ability to effect change. Many observers in the $19^{\text {th }}$ century shared the opinion of John Quincy Adams, who counseled the still weak country against going out to find dragons to slay. This limitation was somewhat alleviated by the subsequent rise in U.S. power, but first the Cold War and then the Vietnam War demonstrated that the United States still did not have sufficient power, or will, to spread its ideas to all countries.

A second limitation was U.S. wariness of multilateral institutions and international legal commitments. For much of its early history, the country followed George Washington's advice against forming long-term alliances and multilateral commitments. After World War II, though, the United States responded to new global conditions by helping establish and joining many new institutions and treaties. Still, the country retained some wariness of formal commitment. For example, U.S. representatives played a major role in drafting the Universal Declaration of Human Rights in 1948, but promoted a document that laid out aspirations and ideals, not legally binding requirements. ${ }^{7}$ Subsequently, the United States remained outside of many key international agreements such as the UN Covenant on Civil and Political Rights and the Covenant on Social, Economic, and Cultural Rights. In several cases, the United States also openly disregarded decisions by the International Court of Justice (World Court).

Third, pursuit of human rights policies was limited by competing policy priorities. This problem can be seen even early in U.S. history in debates about whether to ally with France or England, but it was particularly dominant during the Cold War era. Containment of communism and security interests frequently outweighed human rights concerns. When human rights 
policies were in line with containment, for example in criticizing communist regimes, or when they could be pushed in less strategically important areas, they were pursued. On the other hand, when anticommunist credentials and political stability were deemed necessary, the United States was willing to mute criticism of pro-Western dictators.

Finally, full implementation of a human rights policy was constrained by the limited institutional power of governmental human rights advocates and by minimal domestic political support for a human rights focus. In the U.S. foreign policy-making process, an idea, no matter how worthy, will not be implemented unless it has strong and savvy supporters who are able to push it through the various bureaucratic or congressional debates. Weakness of human rights advocates was partially ameliorated by the creation of the State Department's Human Rights and Humanitarian Affairs Bureau in 1977 and the rise of non-governmental human rights organizations in the 1970s. In its early years, though, the Bureau was given little respect or cooperation by other bureaucratic players. ${ }^{8}$ The NGOs had limited funding and policy expertise and often were excluded from the relatively closed foreign policy-making system of the era.

Thus, although there is a long-standing American tradition of rhetorical support for human rights and several historical and institutional changes led to development of a human rights policy, translating ideals into practical application was difficult. Analysts looking at any given period through the 1980s could point to new ways human rights were shaping policies, but were also left acknowledging, and often lamenting, the particular era's constraints on full implementation. ${ }^{9}$

\section{New Focus In A New PERIOD}

The end of the Cold War and other contemporaneous shifts appeared to finally remove all the long-standing limitations on U.S. human rights policy. Many felt that the United States now stood alone as a hegemon and had the power to influence decisions in countries around the globe. The collapse of communism also led many to agree with Francis Fukuyama's idea that history had reached its end and liberal democracy had emerged triumphant. ${ }^{10}$ Therefore, the 
United States, as the leading democracy, would just have to nudge a few recalcitrant states into line with the inevitable. Global trends also appeared favorable. Increased economic globalization seemed to enable the United States and other leading powers to use trade and other economic policies as carrots and sticks to enforce human rights. ${ }^{11}$ Also, state sovereignty appeared to be weakening. The international community increasingly accepted the idea that powerful countries, like the United States, would lead international efforts to bring recalcitrant states' policies in line with international norms.

The United States still retained some wariness of multilateralism and was unwilling to accept the levels of internal monitoring and joint action seen in the polices of other global human rights leaders, ${ }^{12}$ but there were important shifts in U.S. attitudes beginning in the late-1980s. During the Cold War, U.S. officials were often hesitant to establish powerful U.N. agencies. They feared that the Soviet Union and its communist allies, perhaps in conjunction with newly independent states that might see some Western actions as reminders of colonial imposition, would skew U.N. debates and definitions of which rights should be protected. Moves toward democracy in Russia, Eastern Europe, and the developing world reduced those worries. The end of the Soviet veto in the Security Council also increased the chance of U.S.-controlled multilateral action. Finally, after the long Cold War, the United States was looking to shift some of the burden of world responsibility to its allies and multilateral institutions.

The Cold War's end also took away major competing policy priorities. With the Soviet threat gone, the United States appeared to have new flexibility in bilateral relationships and overall strategic planning. Human rights goals could rise and security considerations decline. Particular country-specific interests such as counternarcotics goals in Colombia, military cooperation in Turkey, or regional cooperation in Egypt remained to complicate policy priorities, but there appeared to be no global doctrine that would conflict with the pursuit of human rights.

By the late-1980s, the policy-making position of human rights advocates had been strengthened by institutional growth of both governmental and non-governmental agencies. Also, the foreign policymaking system opened somewhat after Vietnam to allow more 
independent activity by Congress, the press, interest groups, and the general public. Support from non-governmental actors became increasingly crucial and their access to decision-makers increased.

Taken together, the various changes of the late-1980s appeared to have removed the old limitations. The United States was powerful, more willing to act multilaterally, free of major competing priorities, and had stronger human rights advocates. Therefore, within many government, NGO, and academic circles, there was great optimism that a new policy era had emerged and human rights considerations could move forward unencumbered. ${ }^{13}$

Before examining the extent to which human rights policies in this new era have or have not matched that optimism, it is important to note a couple methodological ideas. For the purpose of this argument, the post-Cold War era will be defined as beginning in 1991. The major policy event of that year, the Persian Gulf War, was a harbinger of policies to come, not a throwback to the Cold War era policies. Therefore, the period includes the end of George H.W. Bush's presidency and the presidencies of Bill Clinton and George W. Bush. There are differences among the viewpoints and rhetoric of these three presidents. For example, the elder Bush pursued more ad hoc policies, while Clinton laid out a grander vision and had more commitment to international organizations. ${ }^{14}$ Clinton and the younger Bush have important differences on how to define rights and how to pursue objectives. For definitions, Clinton usually drew off existing international treaties and common law, while Bush has put more focus on the less legally binding idea of God-given human "dignity." On tactics, Clinton often acted multilaterally, while Bush is more willing to act unilaterally. ${ }^{15}$ These differences are real, and reflect both ideological disputes and the very different world conditions faced by each president. However, if one examines the specific country policies followed by the three presidents, there is significant and important continuity. Also, differences in presidential tactics are very often differences of degree, not kind. The human rights literature commonly analyzes policy development by administration, but this paper will focus on substantive policy trends across the three administrations. 


\section{THE STEPS FORWARD}

Since the end of the Cold War, increased focus on human rights in policy-making has continued. The steps forward are diverse, but can be organized around four main themes: rhetorical support for human rights, proactive measures to spread democracy and rights, new targeted legislation, and new acceptance of international human rights treaties and legal authority.

\section{Rhetorical Support}

All three post-Cold War presidents have laid out an overall vision guiding policy. All three visions have incorporated and strengthened the idea of pursuing human rights and democracy. In justifying the Persian Gulf War, George Bush spoke of an emerging "New World Order" based on international norms and rights. ${ }^{16}$ Clinton, and his National Security Advisor Anthony Lake, looked for a vision to replace containment and spoke of "democratic enlargement" that would "foster and consolidate new democracies and market economies where possible." 17 For George W. Bush, the guiding vision has been defeating terrorism. As will be discussed later, this vision has complicated the pursuit of a human rights agenda, but Bush has also reinforced the idea that, in order to defeat terrorism and assure security, America must lead the fight for individual rights. In his 2002 State of the Union address Bush explained, "America will lead by defending liberty and justice... [and] will always stand firm for the non-negotiable demands of human dignity: the rule of law, limits on the power of the state, respect for women, private property, free speech, equal justice, and religious tolerance." 18 The National Security Strategy of the United States of America issued in September 2000 pledged to "press governments that deny human rights." 19

Beyond these sweeping visions, the promotion of human rights has become a regular part of arguments used to justify many policies. Crucially, it is now often argued that the United States need not choose between human rights and other interests, because defense of human rights aids other interests. This view stems partly from acceptance of the academic conventional wisdom that no two democracies have ever fought each other. Furthermore, many government officials believe that countries with good human rights records are more likely to work with the 
United States on transnational issues like drugs and proliferation, to engage in more trade, and, in the words of one State Department official, to be "the best partners and only true allies for our nation." 20 These statements show that human rights promotion is fully entrenched as a U.S. policy goal.

\section{Proactive Policies}

Traditionally, human rights policies have focused on criticizing violators and punishing them through a variety of symbolic, economic, and legal means. In the post-Cold War period, the United States has continued to implement such polices. For example, the State Department's Annual Report on Human Rights, whose influence is illustrated each year by the strenuous denials and counter-attacks advanced by countries singled out for criticism, has been strengthened. Also, the United States has leading diplomatic efforts to punish violators in places such as Serbia, Haiti, Iraq, Zimbabwe, and Burma. Importantly, though, the United States has increasingly adopted more proactive policies that attempt to stop abuses before they occur and give greater reward for human rights progress.

One sign of this shift has been the rise of humanitarian interventions. There are always multiple interests driving major military interventions, but U.S. actions in Somalia, Haiti, and Kosovo were driven to a large degree by human rights and humanitarian priorities. Operation Restore Hope in Somalia was prompted by humanitarian desires to stop the civil war and establish order so that food relief could reach the starving population. ${ }^{21}$ In Haiti's case, the refugee issue played a major role in policy calculations, but even once much of that flow had been reduced, Clinton tried a number of pressures and appeared ready to fight for democracy in Latin America. ${ }^{22}$ Ultimately, a major invasion was headed off only by last minute negotiations that restored to power the democratically elected President Jean-Bertrand Aristide. In Kosovo, the United States led NATO efforts aimed at stopping Serbian abuses. ${ }^{23}$ Importantly, this intervention occurred against an existing government acting in its sovereign territory. None of these interventions proved entirely successful, but it is striking is that they were made at all. 
They demonstrate that the United States was willing to use force to change the internal governance and conditions within other countries even when security interests were minimal.

The U.S. has also tried to change conditions through non-military means. New focus has been put on the idea of building civil societies and stable government systems that will protect citizens' rights. These ideas are not entirely new and gained momentum with the creation of the National Endowment for Democracy during the Reagan administration, but they have reached new heights. In recent years, the United States has spent over $\$ 700$ million per year on programs to promote democracy. ${ }^{24}$ Through programs such as the Human Rights and Democracy Fund (HRDF), these monies go to help monitor elections, train legislatures, develop political parties, promote judicial reform, and support trade unions. These and other programs will likely expand if Bush pursues his goal of bringing democratic reforms to the Middle East.

The proactive policies have also included efforts to encourage reform through carrots rather than sticks. In March 2002, Bush announced the creation of a new development fund, the Millennium Challenge Account (MCA). The new $\$ 5$ billion per year program will distribute aid only to countries that are "ruling justly, investing in their people, and encouraging economic freedom." 25 To be eligible, countries must meet per capita income requirements. They are then scored on 16 data indicators: six on governing justly, four on investing in people, and six on promoting economic freedom. Countries must score above the median for their income group on at least half of the indicators in each area and above the median on corruption. The hope is that the program will lessen corruption and waste in U.S. aid programs, give countries an incentive to implement economic and political reform, reward countries that are succeeding, and help alleviate some of the causes of human rights abuse such as poverty and excessive state control. The program has been slow to become fully operational. Implementation questions also remain, such as whether the program is so targeted that it will exclude many of the world's poorest, or conversely whether it will become so broad that it risks becoming politicized in ways that have hurt past programs. Many development and human rights groups have welcomed MCA as a new tool to induce change. The embrace of aid and human rights criteria by a conservative 
Republican president has been described as having a "Nixon-goes-to-China flavor"26 and is another indication of how human rights goals have become important components of U.S. policy.

\section{New Targeted Legislation}

A third development of this new era has been a shift to targeted legislation. During the Carter period, the focus was on broad legislative restrictions on U.S. foreign aid. Often referred to as 502B restrictions, the law states that no security assistance may be provided to any country that

engages in a "consistent pattern of gross violations of internationally recognized human rights." 27 In practice, however, aid only rarely has been restricted. ${ }^{28}$ Neither the executive branch nor Congress has wanted to antagonize U.S. allies by labeling them as abusers, and even nongovernmental human rights leaders like Aryeh Neier note that 502B is "like an atom bomb; it may have more benefit before you actually use it." 29 In response to the step back of nonenforcement after the step forward of passing the legislation, congressional human rights leaders in the post-Cold War period have advanced more targeted legislation. In some cases, this has meant new restrictions on trade with or aid to specific countries such as Burma, Indonesia, or Colombia. In two other significant cases, the Leahy Law and International Religious Freedom Act, it has meant new global restrictions on ties with specific kinds of violators.

With an eye toward restricting U.S. aid to Colombia without having to use the all or nothing approach of 502B, Senator Patrick Leahy (D-VT) sponsored an amendment to the 1997 Foreign Operations Appropriations Act (P.L. 104-208) that prohibited U.S. counternarotics aid to any specific military unit that had committed a gross violation of human rights. The following year, the prohibition was extended to all forms of aid to security forces paid through the 1998 Foreign Operations Appropriations Act (P.L. 105-118). Then, in 1999, similar language prohibiting U.S. military training of violators was added to the Defense Appropriations Act (P.L. 105-261). These terms are often referred to as the "Leahy Law;" however, because they are actually appropriations riders, they must be renewed each year as part of the appropriations cycle. The Leahy language brought three significant changes. First, the law theoretically keeps 
U.S. aid out of the hands of actors that are among the worst violators because it targets military units who often lead state abuse. Second, the law promotes prosecution of violators because aid can be continued if the recipient country is taking action to bring the offenders to justice. Third, and most crucially, it gives the United States a targeted human rights tool to supplement the blunt weapon of 502B. In 1998, the law stopped the Turkish Anti-Terror Police from purchasing armored vehicles. Subsequently, it has affected discussions with Indonesia, Mexico and others. In late-2002, the Bush administration announced that, for the first time, it was suspending aid to a Colombian Air Force unit accused of using helicopter-launched rockets against civilians.

New targeted legislation has also been put in place to punish countries that violate religious freedom. The International Religious Freedom Act (P.L. 105-292) was signed into law on October 27, 1998 after several years of work by faith-based organizations and religious conservatives in Congress. ${ }^{30}$ The law establishes an Office on International Religious Freedom within the State Department led by an Ambassador at Large. The office monitors religious persecution, recommends policies to promote freedom, and compiles its own report in conjunction with the annual human rights reports. The law also provides a long list of actions the president can take to punish violators. More of the sanctions were mandated in original drafts of the legislation, but the Clinton administration pressed for flexibility in determining which countries should be targeted, what actions should be taken, and when the sanctions could be waived. Some observers have complained that this flexibility allows the administration too great an ability to avoid criticizing allies. ${ }^{31}$ At a minimum, though, the law adds another layer of review and potential condemnation and punishment, so that violators may be induced to change their policies.

\section{International Treaties and Legal Authority}

A fourth post-Cold War development was increased United States participation in international agreements and multilateral institutions. Since 1988, the United States has ratified four international human rights treaties that it had ignored for decades. Conventions on Genocide, 
Torture, and Racial Discrimination, along with the fundamental International Convention on Civil and Political Rights, were all ratified by 1994. As will be discussed in more detail later, the ratifications came with some "reservations" and "understandings." Also, in 1998, Clinton signed an executive order stating that it is the policy and practice of the U.S. government "fully to respect and implement its obligation under international human rights treaties to which it is a party." 32 These ratifications and commitments simply brought the United States in line with much of the rest of the international community that had already ratified the agreements, but they were an important symbol of a new U.S. attitude as the Cold War ended.

The early-post Cold War years also saw the United States working much more often through the United Nations. The most visible sign of this new attitude was that the United States went to the U.N. for resolutions of support and justification for actions in the Persian Gulf, Somalia, and Haiti. In each of these cases, the decision to act was really made in Washington, but U.N. support was seen as politically important to reinforce the idea of a new world of international human rights norms and cooperation. The U.S. has also been supportive of U.N. actions in Cambodia and East Timor.

U.S. efforts in the early 1990s to buttress the U.N.'s institutional capabilities on human rights have garnered less attention, but are also important. Under George H.W. Bush, Assistant Secretary of State for Human Rights Richard Schifter pushed the U.N. Human Rights Commission to be more active and investigate high profile countries. ${ }^{33}$ Also, during the Cold War, the United States had given rhetorical support to the idea of developing a U.N. High Commissioner for Human Rights, but U.S. diplomats acknowledge that the idea was never given active support. ${ }^{34}$ Under Clinton, however, the United States made the project a priority. In 1993, the office of the U.N. Human Rights Commissioner was established as a full-time human rights watchdog.

One final way that the United States has shown support for multilateral actions and international law was by supporting formation of the International Criminal Tribunals for Yugoslavia and for Rwanda. ${ }^{35}$ The United States also used sanctions and other pressures to 
encourage countries to cooperate with the tribunals. Established in 1993 and 1994 respectively, these tribunals were the first international war crimes tribunals since the post-World War II Nuremberg trials. Although their long-term impact remains to be seen, the tribunals have been important symbols of new international agreement on norms of behavior. Additionally, they have established international case law and precedents, shown that even top political leaders can face possible prosecution and punishment, and possibly deterred future abuses by those fearing punishment; however, this last point is widely contested. U.S. support for the tribunals showed that the United States would acknowledge and promote the legitimacy of international courts in certain cases.

\section{Continued Limits ON POWER}

As the Cold War ended, the United States appeared ready to dominate the world, but the following decade clearly has shown that important barriers to U.S. influence still exist. The overall local conditions of countries that the United States hopes to influence and the determination of particular leaders to act as they see fit despite international condemnation remain two great barriers to U.S. influence. These factors will not change significantly no matter how much economic or military power the United States amasses. Too often, optimistic observers, including some U.S. government officials, assume that if the United States just focuses its attention on a particular country, and especially if it takes active steps like sanctions or military intervention, years of local history will simply vanish as indigenous people see the light of U.S. wisdom. For example, when the United States acted in Somalia, some officials initially believed that the mission could be completed in a month's time. When the U.S. phase of the mission continued instead for five months, there was real impatience and annoyance with the U.N. for failing to step in to assume responsibility so that U.S. troops could withdraw. There was also a degree of shock and betrayal expressed in the following fall, when eighteen U.S. soldiers were killed by a Somali faction that did not accept the U.N.'s plans for a new Somali government. Similarly for Haiti, Bosnia, Chechnya, and elsewhere, critics tend to assume that 
anything short of total success is a sign of U.S. inattention or mistakes, not the result of complicated local histories that the United States can influence only at the margins.

Cases such as Serbia, Iraq, North Korea, Cuba, Zimbabwe and others defined as "rogue states," also show that U.S. power to influence is severely limited if leaders are determined to act despite international displeasure. ${ }^{36}$ One must not forget that the prime goal for many leaders is to maintain power no matter what actions that requires. Also, leaders are well aware of international standards, so their violations come not from ignorance, but from policy calculations that certain steps are necessary or justified given local conditions. When the Cold War ended, many assumed that, with Soviet support gone, governments would be forced to yield to U.S. power, but this view neglected to give proper weight to Rep. Thomas P. (Tip) O'Neill's famous comment that "all politics is local."

Furthermore, U.S. power to bring about human rights change has been limited by four developments in the post-Cold War era. First, the spread of a global economy, at times, has constrained instead of enhanced U.S. power. ${ }^{37}$ The United States itself is increasingly dependent on trade and access to foreign markets and investment opportunities. Therefore, if the United States threatens economic sanctions, violators can try to call the U.S. bluff, and force the United States into a decision that could hurt its own economy. Also, the global economy means that there are many other countries ready to step in to replace lost investment, imports, and export markets if a country loses U.S. business. The classic case of these economic realities is China. George H.W. Bush supported continued trade with China despite the government's action at Tiananmen Square. In 1993, Clinton imposed human rights conditions on China's Most Favored Nation (MFN) trade status and set up a one year game of chicken. By the spring of 1994, China clearly had not met the conditions, but only a minority of Congressmen and few in the administration were actually willing to limit U.S. trade. This hesitation was reinforced by the fact that America's European allies had long since ended their punishments of China and were actively looking to increase business in China should the United States pull out. In response to these realities, Clinton dealt the human rights community one of its greatest losses by de-linking 
human rights and trade and adopting a strategy of engagement with China. ${ }^{38}$ Until postSeptember 11 cooperation, George W. Bush took a harder line on China's potential to be a threat to the United States, but he too favored expanded trade.

The European defection on China also highlights a second new limit on U.S. power. Namely, the United States can no longer automatically count on the support of its allies in pressing human rights concerns. For years, international human rights alliances followed Cold War alliances. Democratic countries generally were in agreement and saved their toughest criticism for communist countries. Furthermore, it was accepted that major disagreements within the alliance should be muted, so that it could remain strong against its enemies. Recently, though, with the unifying Soviet threat gone, U.S. allies have shown more independence on a host of issues, including human rights. As many countries move toward various forms of liberal and illiberal democracy, the United States and its allies are hard-pressed to agree on who deserves human rights pressure. European allies have had sharp differences with the United States on policies toward Cuba, Iran, Iraq, China, and the Middle East. There is also more difference now on tactics. While the United States often turns to military and economic pressures, European governments more often address human rights through engagement, dialogue, and treaties. ${ }^{39}$ Europeans also have argued that the United States has followed a unilateralist foreign policy with little consultation. Without allied support, the United States may be powerful by some measures, but it lacks both the moral authority and resources to challenge every violator.

The combination of the global economy giving countries multiple sources for trade and the lack of allied cooperation has led many observers to conclude that a third limit on U.S. power is that sanctions rarely achieve their intended purpose. Sanctions often appeal to those who are looking for action tougher than simple criticism. By 2001, some form of sanctions had been placed on 72 countries for a variety of offenses including human rights violations. ${ }^{40}$ Numerous academic and other studies have shown, however, that sanctions_-particularly unilateral sanctions as many U.S. human rights action are-have a poor record of inducing policy 
change. ${ }^{41}$ Furthermore, they can also hurt the U.S. economy. Business groups and coalitions like USA Engage frequently argue that sanctions hurt the American people. Worse still is the pain that may be inflicted upon the very people the sanctions are designed to protect. In Iraq, in Haiti, and elsewhere, there are real questions of whether the denial of food, medicines, safe water and so on may not have been worse human rights violations than anything that the indigenous government had done. Human rights sanctions blossomed for the first part of this decade, but now both George W. Bush's administration and congressional figures have called for their reduction. Problematically, policy-makers are thus left with few options between criticism and intervention. The net effect may be fewer punishments of any kind.

A final new development limiting U.S. power to enforce human rights policies is that the violating countries have become much more savvy and active in combating U.S. and U.N. efforts. Countries have learned that, in the human rights arena, image is very important. Rather than allowing the United States and others to paint their image, countries now go on the offensive. They release political prisoners at strategic times, challenge the State Department's annual report almost before it has been released, and raise complaints against other countries that will deflect attention away from them. Frequently criticized countries also realize that they can block much action if they join human rights institutions. Cuba, Syria, Sudan, and China have all found that seats on the U.N. Human Rights Commission and careful lobbying of members can blunt many U.S. efforts. These countries do not allow the United States to rally international pressure; they nip actions in the bud.

In fact, the recent history of the U.N. Human Rights Commission is a good view into many of the power problems the United States faces. Commission members are elected to represent their regions of the world. Given U.S. leadership in the human rights field, the United States had held one of the Western Europe and Others Group seats since the commission's founding. In 2001, though, the United States came in fourth in a race for three seats. The loss has been attributed by various observers to a combination of U.S. inattention to U.N. diplomacy, European desire to punish U.S. unilateralism, and the power of accused violators who rallied 
voting countries against the United States and in favor of Austria, which itself had been criticized by international bodies. $^{42}$ In 2002, the United States was able to regain its seat, but the commission had been much less active in the intervening year. For example, the United States could not find any country willing to sponsor a tough resolution against China. A former public member of the U.S. delegation attributed the reluctance to Chinese threats to economically punish countries that acted against China in international forums. ${ }^{43}$

These various limits on U.S. power and policy setbacks reinforce the idea that, while there have been many changes in the international system in recent years, fundamentally it is still based on state sovereignty and pursuit of national interests. ${ }^{44}$ Although the United States stands as the only multi-dimensional power and is far ahead of its competitors, it cannot always dictate polices to either target countries or to its allies. In principle, the United States could use its power to bring regime changes and engage in long-term, colonial style occupations that might or might not bring about desired local changes. Such actions, however, would go against new global and American norms against imperialism. Only time will tell if U.S. actions in Afghanistan and Iraq — both interventions driven by security goals but with important human rights implications - will establish a new paradigm. Early evidence from those countries, added to evidence of limits on U.S. commitments to and ongoing problems in Haiti, Somalia, and the former Yugoslavia, seems, though, to confirm both American distaste for long-term occupations and nation-building and to show that local realities are the most crucial variable in determining a country's path to stability and democracy.

These limits on U.S. power suggest why U.S. human rights policies are often not successful, but also have affected the chance that efforts are made in the first place. The American public and many government officials want to see short-term success. If positive change is not guaranteed or occurs slowly, Americans often becomes frustrated or lose interest, and policies are scaled back. Therefore U.S. human rights policy in the future likely will look much as it has in the past with the U.S. pressuring countries from the outside and often failing in its goals. 


\section{Continued Resistance To InTERnational AgREEMENTS And Actions}

As was discussed earlier, the post-Cold War era has seen the United States take the forward steps of signing some international treaties and supporting international tribunals. Subsequently, though, it has followed its usual pattern of then taking steps backward. When the United States signed several treaties in the late-1980s and early 1990s, two steps were taken to limit the treaties' impact. First, each ratification was accompanied by a series of "reservations," "understandings," and "declarations" (RUDs). These sought to clarify U.S. interpretations of particular treaty language and to lay out what actions the United States would or would not take in implementing the treaties. Taken together, the RUDs essentially said the United States would follow the treaties as long as they were consistent with existing U.S. law and would implement the treaties without accepting any obligation to change U.S. law or policy. ${ }^{45}$ These positions were in line with long-held beliefs that the U.S. Constitution is the highest law in the land and grants Congress the exclusive power to consider and create all laws. Thus, the validity of treaty guarantees that go beyond constitutional guarantees are questionable and treaties that would require the United States to change laws are problematic.

RUDs are common international practice, but the U.S. RUDs raised the question of whether the United States was actually following the treaties at all. In November 1994, the U.N. Human Rights Commission adopted a general statement on RUDs with a clear focus on the U.S. positions. In that statement, the commission expressed "regret" at the U.S. positions and argued that specific U.S. reservations to the Covenant on Civil and Political Rights were "incompatible with the object and purpose of the Covenant." ${ }^{46}$ Since then, the United States has not ratified any other major human rights treaties. Given the current focus on George W. Bush's unilateralism, it is important to remember that the RUDs and slowdown in treaty signing began before his administration.

The second United States move to limit the impact of the treaties brought back the idea of "Brickerism." Senator John Bricker was a fierce opponent of the United Nations, international legal commitments, and international human rights treaties specifically. In the 
early-1950s, he led a movement for a constitutional amendment that would have made treaties non-self executing, meaning they would only become valid once Congress passed specific legislation implementing their terms into U.S. law. ${ }^{47}$ Bricker's amendment would have asserted a large congressional role in foreign policy-making and served his express purpose: "to bury the so-called Convention on Human Rights so deep that no one holding high public office will ever dare to attempt its resurrection." 48 The movement gained momentum. To assure the measure's close defeat and protect its overall constitutional powers, the Eisenhower administration promised that the United States would not ratify the conventions if Bricker's amendment was defeated. Future administrations moved away from that promise, but for several human rights conventions they returned to Bricker's idea that the treaties should be non-self executing. This requirement places an extra hurdle in the ratification process and provides a way for the United States to symbolically support human rights by ratification without having to accept any real changes in U.S. policies.

In addition to placing limits on the treaties it has ratified, the United States also has chosen not to join several international treaties that relate more or less directly to human rights. The United States refused to join the over 100 countries that signed the 1997 Land Mines Treaty after U.S. demands for changes in the treaty were denied. The United States has been slow to accept international efforts to stop the use of child soldiers because of its own efforts to recruit 17 year olds into military service. ${ }^{49}$ The United States has signed, but not ratified, the Convention on All Forms of Discrimination against Women and the Convention on the Rights of the Child.

A desire to limit the impact of international agreements also explains U.S. reaction to the International Criminal Court (ICC); the reaction provides a classic illustration of American views. In some ways, the court is the culmination of years of U.S. effort to bring order to the international system and find new ways of punishing violators. Clinton endorsed the goal of establishing the court in 1995, and the U.S. delegation was active in shaping the Rome Statute of 1998 that established the court. The ICC also seems similar to the tribunals on Yugoslavia and 
Rwanda, which were strongly supported by the United States. There are, however, two important distinctions: first, the ICC operates more independently of the U.N. security council and thus, in theory, more independently of great power control; second, U.S. troops or government officials could some day face charges by the Criminal Court.

Over time, officials from both the Clinton and Bush administrations have expressed other concerns about the court. ${ }^{50}$ For example, there has been concern that the Rome Statute's definitions of international crimes are vague, open-ended, and not subject to reservations. There have again been questions about the constitutionality of forcing U.S. adherence to laws not passed by Congress. There has also been major criticism of Article 12 of the statute, which states that the court may assert jurisdiction over certain crimes committed on the territory of a state party, including crimes committed by nationals of a non-party. Thus, even if the United States does not ratify the statute, its soldiers could be brought before the ICC if they committed a crime while in a ratifying country. U.S. officials have stated that this article goes against treaty law by making a non-party subject to a treaty. From a practical perspective, this article only becomes a problem if the United States chooses not to ratify for other reasons.

The interrelated questions of U.S. control and possible trials of Americans have been the two central issues hindering U.S. acceptance of the ICC. During negotiations, the U.S. delegation pushed hard for U.N. Security Council control of the court, which would have enabled the United States to veto politically motivated investigations of U.S. citizens. Other countries argued for an independent court. In the end, the United States accepted a compromise that gave the ICC prosecutor much independence, but allows the Security Council to pass a resolution to suspend an investigation or prosecution for one year. ${ }^{51}$ Some U.S. officials still felt the prosecutor was given too much latitude. Also, many argued that United States soldiers and officials were at greater risk of prosecution because of America's greater world role. Clinton officials thus pressed for several ways to limit the chance that Americans would be brought before the court. ${ }^{52}$ Most crucial was the principle of complementarity, which means that the ICC cannot proceed with an investigation or prosecution of a crime that is being or has been 
investigated or prosecuted by a state that has jurisdiction, unless the state is unwilling or unable to carry out a fair investigation or trial..$^{53}$ Thus, if a U.S. soldier was accused of a crime, the case could go to the ICC only if the U.S. judicial system failed to genuinely investigate the allegation and proceed with a fair trial. Thus, the chance of an American being but put on trial was low, but still present.

Based on these concerns, the United States was one of only seven countries to vote against the Rome Statute. Clinton signed the Statute on December 31, 2000, the last day that countries could become party to the treaty without formal ratification. As he did so, however, he discussed "significant flaws in the treaty," said he would not submit the treaty for ratification. ${ }^{54}$ He pledged to work for evolution of court rules. George W. Bush has expressed even deeper concern about the court and taken more assertive action. First, in May 2002, as the court was about to begin operation, Bush notified the U.N. that the United States had no intention of becoming a party to the statute and was essentially "unsigning" the treaty. Bush administration officials felt this unprecedented action was necessary because complementarity is "simply an assertion, unproven and untested." 55 They were worried about the potential damage if investigations of either U.S. servicemen or U.S. leaders occurred and they oppose the idea that the ICC ultimately decides whether a national court system has acted fairly. The administration, therefore, took steps to assure that Americans would not be turned over to the ICC. In July 2002, the Bush administration delayed reauthorization of the U.N. peacekeeping mission in Bosnia as it sought permanent immunity of peacekeeping troops from ICC prosecution. U.S. actions were sharply criticized by European and U.N. officials. A compromise was struck that prohibited the ICC from investigating peacekeepers from non-ratifying countries for one year. A similar resolution was passed in 2003, but the Bush administration chose not to pursue another renewal in 2004 after it became clear that such a resolution would not pass. Meanwhile, the United States pressed hard for countries to sign bilateral agreements under Article 98 of the Rome Statute. In the agreements countries pledge not to surrender U.S. citizens to the ICC. By the summer of 2004, the United States had concluded over 90 agreements, but these agreements 
have been sharply opposed by many European countries. In August 2002, Bush signed the American Servicemembers' Protection Act (P.L. 107-206), which prohibits U.S. military assistance to countries that are party to the ICC and do not sign Article 98 agreements. The legislation also authorizes the president to use force to release any U.S. citizen held by the court.

Taken all together, these actions show that the United States supports international treaties and courts as long as they are not applied to U.S. citizens and do not interfere with either U.S. domestic policies or U.S. military operations abroad. More generally, the United States is once again demonstrating that it supports human rights efforts, but only when it can lead and control those efforts. The U.S. position seems hypocritical to many and may prove shortsighted if U.S. power declines in the future. For the foreseeable future, though, the U.S. position reflects international realities. As was stated centuries ago, "The strong do what they have the power to do and the weak accept what they must accept." ${ }^{256}$ Other countries may object to U.S. actions, but, so far at least, U.S. power has allowed it to act independently without huge long-term costs. Thus, as long as the United States remains the preeminent power, it will resist efforts either to bring its policies in line with the goals of others or to place restrictions on the pursuit of what it considers national interests.

\section{CONTINUED COMPETITION FROM OTHER POLICY PRIORITIES}

As a superpower, the United States has complex global interests and thus has to choose between policy priorities. In the Cold War era, containment of communism trumped all other policy goals. With the end of the Cold War, the United States appeared to have new flexibility. In fact, the last decade has seen the emergence of two new competing priorities, namely, pursuit of global trade and antiterrorism.

Clinton did raise human rights issues in his campaign against George Bush, but it was clear that he was elected because he remembered the famous slogan "It's the economy, stupid." Throughout his eight years, Clinton never lost focus on pursuit of a strong economy and embraced the idea that the United States needed access to foreign markets to continue its growth. 
He worked hard to promote trade pacts like NAFTA and pursued ties with the "Big Emerging Markets." When pursuit of trade conflicted with tough human rights policies, as in the case of China, trade won time and time again. Clinton spoke of democratic enlargement, but as Douglas Brinkley argues, that strategy became increasingly "econocentric" and "was about spreading democracy through promoting the gospel of geoconomics." 57

Soon, human rights advocates were speaking of "The New Double Standard" under which action was taken against only economically unimportant countries. ${ }^{58}$ In the abstract, such a double standard is lamentable, but in the real world it is almost inevitable. Trade is a growing part of the U.S. economy and economic strength is a growing part of what defines modern world power. Human rights must not be forgotten, but those waiting for the United States to sacrifice its perceived economic national interests for the good of humanity will have a long wait.

That wait has now been lengthened by George W. Bush's declaration of war on terrorism. Antiterrorism has replaced anticommunism as the guiding security doctrine. This shift has shaped the allocation of administration time and resources. It also had a crucial impact on U.S. alliances and willingness to criticize human rights violators. Countries that were previously targeted as violators, but which expressed sympathy for U.S. losses and provided counterterrorism aid, were seen in a new light. The government of Ali Abullah Salih in Yemen suddenly was negotiating the arrival of U.S. military trainers and equipment. Malaysia's Prime Minister Mahathir Mohamad, known for his sharply anti-American views and support of a conviction against his rival Anwar Ibrahim in a case the State Department termed "politically motivated and patently unfair"59 was invited to the White House. To reward Pervez Musharraf of Pakistan for his assistance, Bush supported new legislation that allowed him to waive sanctions imposed after Musharraf's 1999 coup. The administration also turned a relatively blind eye to Pakistan's 2002 referendum that extended Musharraf's rule without competitive elections and to modifications of the Pakistani constitution that gave the military a long-term role in politics. 
The war on terrorism also lessened U.S. criticism of countries cracking down on internal groups, if those groups were defined as terrorists. For example, criticism of Russia's actions in Chechnya has declined. Before 9/11, State Department officials met with the foreign minister of the separatist Chechen leadership. After 9/11, a message was sent to separatists in Chechnya demanding that they sever all contacts with terrorists or face American isolation. Bush and other officials subsequently have expressed sympathy for Russian President Vladimir Putin's characterization of the Chechens as Islamic terrorists. ${ }^{60}$ The long-term civil war in Colombia also has been recast as a battle against terrorism since the leftist Revolutionary Forces of Colombia (FARC) frequently engaged in kidnappings and bombings. In the Middle East, the focus has been on cracking terrorist cells, so the administration has not yet pushed hard for democratic reforms in Saudi Arabia and elsewhere.

The war on terrorism has also strained U.S. adherence to international treaties on the treatment of prisoners. In general, the Bush administration has felt security concerns were paramount. Therefore, the administration planned to hold suspected terrorists indefinitely and authorized use of tough interrogation tactics to acquire intelligence that might prevent future attacks. In the fall of 2001, top administration officials repeatedly referred to Taliban and $\mathrm{Al}$ Qaeda detainees held at Guantanamo Bay, Cuba as "unlawful combatants" and argued that they did not qualify as POWs under the Geneva Conventions. President Bush reportedly confirmed this position on January 18, 2002 in an unreleased legal decision. ${ }^{61}$ On February 7, 2002, Bush partially reversed his policy after pressure from allies, human rights groups, and his own State Department. He decided that, while Al Qaeda detainees still would not be covered, the Conventions would be applied to Taliban captives, although none of them would be granted POW status. ${ }^{62}$ Critics suggested that Bush was misapplying definitions in the conventions and that, at a minimum, the administration was required to follow Article 5 of the third Convention that requires a competent tribunal to determine the status of detainees whenever doubt arises as to their status. ${ }^{63}$ The administration argued that Article 5 tribunals were not necessary because there was no doubt about the detainees' status. 
Treatment of prisoners at Guantanamo Bay and elsewhere has also drawn criticism. In the wake of abuse cases at Abu Ghraib prison in Iraq, attention has focused on a August 2002 Justice Department memo written to guide CIA treatment of al Qaeda detainees and a March 2003 Defense Department report that covered actions at Guantanamo. The Justice Department memo laid out a narrow definition of torture and advised the White House that torture "may be justified" and legal as part of the President's efforts "to prevent further attacks on the United States by the Al Qaeda terrorist network."64 The Pentagon report was based partly on the Justice memo and went beyond standard military doctrine in laying out acceptable interrogation techniques such as adjusting the temperature to uncomfortable levels, serving cold rations, and reversing sleep cycles from night to day. ${ }^{65}$ The White House disavowed the Justice memo and took the unusual step of releasing previously classified documents in an effort to show that Bush never approved torture. However, the overall tough policy on detainees joins the post-9/11 alliances and support for global crackdowns in reinforcing the idea that security interests, like economic interests, still trump human rights concerns and will as long as the United States continues to face security threats. A situation that will continue for the foreseeable future.

\section{CONTINUED WEAKNESS OF Human Rights Advocates}

Human rights seemed well positioned at the start of the post-Cold War era from the standpoint of bureaucratic and NGO power. The State Department's Bureau on Democracy, Human Rights and Labor was now institutionalized. ${ }^{66}$ Offices focusing on human rights or the promotion of democracy were being established at the National Security Council, Agency for International Development, the Pentagon and in the economic agencies. Furthermore, particularly during the Clinton administration, key positions were filled with long-time human rights advocates. Clinton's Secretary of State Warren Christopher had been active on the issue during the Carter administration. Assistant Secretaries of State for Human Rights John Shattuck and after him Harold Hongju Koh both were well-known and well-respected human rights advocates. These leaders and many of the staff they brought with them had close connections to private human 
rights groups like Human Rights Watch and Amnesty International. They established much closer working relationships between government and non-government actors. Additionally, the non-government actors were themselves much better funded, staffed, and respected than they had been in the 1970s. It is, therefore, noteworthy that a mere decade later, human rights advocates appear to have become disorganized and weak, and have lost some popular support.

Ironically, part of the movement's new disorganization stems from the fact that the world has changed in directions that the advocates favored. The global spread of democracy, fall of particular dictators, and systemic changes in countries like South Africa have lessened abuse, but also taken away the movement's easy targets. Russia and China continue to face criticism on some issues, but are not the totalitarian dictatorships of the past. Sustaining criticism of and rallying indignation against countries that still have some undesirable traits but are moving toward democracy has proven difficult. Different groups inside and outside of government have therefore taken opposite positions on which countries should be praised for progress or criticized for slowness. Advocates have also disagreed on which tactics should be employed. For example, during the China MFN debates, business groups maintained a consistent voice for one policy. Within the human rights community, however, some supported engagement while others favored punishment. Thus, there was less strong policy advocacy overall. With so few issues unifying the entire governmental and non-governmental community, supporters of action on a particular country or issue are often isolated voices that are easily overwhelmed by supporters of other concerns.

Human rights concerns also suffer from the continued institutional weakness of their chief governmental supporters. State's human rights bureau has come a long way from its early days, but is still viewed warily by other bureaucrats. ${ }^{67}$ Many feel that the Bureau simply repeats a mantra of human rights points without considering overall policy calculations or changing conditions. Even when they meet with Human Rights Bureau officials, other officials often tune out the message. Also, many see the Bureau as a mouthpiece for non-governmental groups rather than a source for independent analysis. Therefore, the recent access many human rights 
advocates have enjoyed may actually have hurt their cause by reinforcing the view that they have “captured" the Bureau. The Bureau's overall position is illustrated by looking at its most significant work, the annual reports. These reports have become institutionalized, and likely will continue for years. They also have been given more respect over time. Still, though, there often appears to be little connection between the Bureau's reports and overall policy. Countries are sharply criticized, yet aid is not cut off under 502B or other legislation, trade is continued, and diplomatic relations with violators continue after adjusting for their annual bump in the road. In addition to the Bureau, there are other governmental actors that support human rights, but those in Congress and other executive branch agencies typically push pet projects and particular concerns, not overall policy development. ${ }^{68}$

Given the weakness of governmental actors, human rights policy depends disproportionately on pressure from interest groups and the public. Human rights groups first began to blossom in opposition to President Nixon's policy of realpolitik. They gained momentum during Carter's presidency, and then came to real prominence during the Reagan era when they often sharply disagreed with the administration about particular cases and the overall direction of U.S. policy. In some ways, the Reagan years were difficult, but many human rights leaders agree that the groups ultimately benefited from Reagan's opposition. ${ }^{69}$ During that era, human rights debates centered on disputes over the facts of who was a human rights abuser. The groups became increasing professional at gathering and disseminating these facts. Also, during that era, the groups stood out as champions for morality and thus garnered much attention and financial support from those opposed to Reagan's policies. In the post-Cold War era, as the administrations themselves put more focus on human rights, the disputes switched away from facts toward difficult policy choices of how to respond to abuse. Also, the groups were no longer criticizing their ideological enemies, but instead former colleagues who had entered government service. The groups had better access, but that often did not always translate into real policy influence. Additionally, when some government action was taken, the groups were left with a tough decision of whether to celebrate a glass half full, or complain about a glass half 
empty. Human rights groups also face new challenges because their major strategy of releasing dramatic reports in the hopes of embarrassing countries into better behavior has lost some of its power over time. The first dramatic report might pressure a country, but years of reports lead many rogue states and others to learn to live with the criticism. Meanwhile, the reports suffer domestically from the problem of "compassion fatigue," a sense that a new problem emerges every time an old one gets settled. Human rights groups are now respected parts of the Washington community, but, unless they find new tactics or new problems to focus on, they are unlikely to jumpstart government policies.

Furthermore, human rights issues have not stimulated major grassroots movements, except in unusual cases like South African apartheid. In polls that ask respondents to rate "promoting and defending human rights in other countries" as a policy goal, significantly fewer than half rate it as "very important."70 Similar results are found for the goal of bringing democracy to other countries. Notably, these polls numbers have been dropping in the post-Cold War era.

One major problem for both governmental and non-governmental human rights advocates is the continued U.S. focus on security and economic interests, which makes their views seem of secondary importance. As noted earlier, these other interests are unlikely to recede any time soon, so advocates will continue to fight an uphill battle. A second problem is that few Americans see human rights abuses abroad as directly affecting their personal interests. Americans may support principles of morality, but evidence of human rights abuse can often be ignored simply by turning off the television. On the other hand, tax increases to increase foreign aid, embargoes that risk American jobs, or long-term military interventions do directly impact average citizens. Politicians know that they are unlikely to lose an election by disappointing the human rights community, but they could lose one if the side-effects of policies hurt their constituents. Lack of public focus and support for tough reinforces the institutional weakness of governmental and NGO human rights advocates. Thus, while human rights groups are now respected parts of the Washington community and have better access to policy-makers, their 
policy influence will likely remain low for years to come unless they find new tactics or new problems to focus on.

\section{CONCLUSION}

Overall, the post-Cold War period has seen important new U.S. human rights actions both bilaterally and multilaterally. Few observers would dispute that a sharply different policymaking environment exists now to that of thirty, or even a dozen, years ago. Still, major structural constraints remain. U.S. power and ability to force change on others is still limited. The United States remains wary of international law and multilateral initiatives that can be applied to U.S. domestic policies or constrain foreign actions. Competing national interests, particularly economic growth and antiterrorism, continue to trump human rights concerns. Domestically, supporters of human rights are still weak actors in the policy-making process. In previous eras, observers often argued a more effective and consistent human rights policy would come if a few variables were altered. The continued existence of key limits in the very different post-Cold War era shows that, in fact, the limits were never short-term, time or issue specific problems, but rather deeper constraints that stem from the realities of global and domestic politics. They did not disappear with the end of the Cold War and they do not vary significantly by administration. 
${ }^{1}$ Quoted in David P. Forsythe, American Exceptionalism and Global Human Rights (Lincoln: University of Nebraska, 1998), 2.

${ }^{2}$ Michael H. Hunt, Ideology and U.S. Foreign Policy (New Haven: Yale University Press, 1987), 19-45; and Arthur Schlesinger, Jr., "Human Rights and the American Tradition," Foreign Affairs 57 (No. 3, 1978): 503-510.

${ }^{3}$ Tami R. Davis and Sean M. Lynn-Jones, “Citty Upon a Hill,” Foreign Policy 66 (Spring 1997): 21.

${ }^{4}$ Jan Herman Burgers, "The Road to San Francisco: The Revival of the Human Rights Idea in the Twentieth Century," Human Rights Quarterly 14 (May 1992): 447-477.

${ }^{5}$ Lincoln P. Bloomfield, "From Ideal to Program to Policy: Tracking the Carter Human Rights Policy," Journal of Policy Analysis and Management 2 (Fall 1982):1-12; Joshua Muravchik, The Uncertain Crusade: Jimmy Carter and the Dilemmas of Human Rights Policy (Lanham: Hamilton Press, 1986); Gaddis Smith, Morality, Reason and Power: American Diplomacy in the Carter Years (New York: Hill and Wang Publishers, 1986).

${ }^{6}$ David P. Forsythe, "Human Rights and US Foreign Policy: Two Levels, Two Worlds," Political Studies 43 (Issue 4 1995): 120-124; and Tamar Jacoby, “The Reagan Turnaround on Human Rights," Foreign Affairs 64 (Summer 1986): 1066-1086.

${ }^{7}$ Forsythe, American Exceptionalism and Global Human Rights, 7.

${ }^{8}$ Edwin S. Maynard, “The Bureaucracy and Implementation of US Human Rights Policy,” Human Rights Quarterly 11 (May 1989): 175-248; and Daniel W. Drezner “Ideas, Bureaucratic Politics and the Crafting of Foreign Policy," American Journal of Political Science 44 (October 2000): 733-749.

${ }^{9}$ The existing literature on U.S. policy is vast, but discussions showing some of these restraints include David P. Forsythe, Human Rights and U.S. Foreign Policy: Congress Reconsidered (Gainesville: University of Florida Press, 1988); David Forsythe, "Human Rights in U.S. 
Foreign Policy: Retrospect and Prospect,” Political Science Quarterly 105 (Fall 1990): 435454; Glenn A. Mower, Human Rights and American Foreign Policy: The Carter and Reagan Experiences (Westport, CT: Greenwood Press Inc., 1987); and Natalie Hevener Kaufman, Human Rights Treaties and the Senate: A History of Opposition (Chapel Hill: University of North Carolina Press, 1990).

${ }^{10}$ Francis Fukuyama, The End of History and the Last Man (New York: Free Press, 1992).

${ }^{11}$ Rebecca R. Moore, “Globalization and the Future of U.S. Human Rights Policy,” Washington Quarterly 21 (Autumn 1998): 193-212.

${ }^{12}$ Kathryn Sikkink, "The Power of Principled Ideas: Human Rights Policies in the United States and Western Europe," in Judith Goldstein and Robert O. Keohane, ed., Ideas and Foreign Policy: Beliefs, Institutions, and Political Change (Ithaca: Cornell University Press, 1993): 139-170.

13 This view was quite widely held, but for a sample of the arguments, see U.S. Department of State Management Task Force, State 2000: A New Model for Managing Foreign Affairs (Washington, D.C.: U.S. Department of State Publications, 1992); Theodore C. Sorenson, “America’s First Post-Cold War President,” Foreign Affairs 71 (Fall 1992): 13-30; and David P. Forsythe, "Human Rights in a Post-Cold War World," National Forum 72 (Fall 1992): 4044. For a competing view that the Cold War's end might lead to a less activist human rights policy, see Alan Tonelson, “Jettison the Policy," Foreign Policy 97 (Winter 1994-95): 121132.

${ }^{14}$ Forsythe, "Two Levels, Two Worlds," 124-128

15 Julie Mertus, “The New Human Rights Policy: A Radical Departure,” International Studies Perspectives 4 (November 2003): 371-384; and L. Kathleen Roberts, “The United States and the World: Changing Approaches to Human Rights Diplomacy under the Bush Administration,” Berkeley Journal of International Law 21 (Issue 3 2003): 631-661. 
${ }^{16}$ Bush first publicly used the phrase "New World Order," in a September 11, 1990 speech to Congress describing response to Iraq's invasion of Kuwait, George Bush, “Out of These Times. . . a New World Order,” Washington Post, 12 September1990.

${ }^{17}$ Anthony Lake, quoted in Douglas Brinkley, "Democratic Enlargement: The Clinton Doctrine," Foreign Policy 106 (Spring 1997):116.

${ }^{18}$ President George W. Bush, "State of the Union Address, January 29, 2002," available at the White House website at http://www.whitehouse.gov/news/releases/2002/01/20020129-11.html.

${ }^{19}$ National Security Strategy of the United States of America, 4, available at http://www.whitehouse.gov/nsc/nssall.html.

${ }^{20}$ Michael E. Parmly, Principle Deputy Assistant Secretary of State for Democracy, Human Rights, and Labor, “The UN Commission on Human Rights," Testimony before the House International Relations Committee's Subcommittee on International Operations and Human Rights, Federal News Service, Inc., 6 June 2001.

${ }^{21}$ Herman J. Cohen, "Intervention in Somalia" in Allan E. Goodman ed., The Diplomatic Record 1992-1993 (Boulder, CO: Westview Press, 1995), 51-80; and John L. Hirsch and Robert B. Oakley, Somalia and Operation Restore Hope: Reflections of Peacemaking and Peacekeeping (Washington, D.C.: United States Institute of Peace, 1995)

22 Douglas Jehl, “Clinton Explains Why He Might Use U.S. Army in Haiti,” New York Times, 20 May 1994; Pamela Constable, "Haiti: A Nation in Despair, a Policy Adrift," Current History 93 (1994): 108-14.

${ }^{23}$ Ivo H. Daalder, Michael E. O'Hanlon, Winning ugly : NATO's war to save Kosovo (Washington, D.C. : Brookings Institution Press, 2000); and Albrecht Schnabel and Ramesh Chandra Thakur, Kosovo and the challenge of humanitarian intervention: selective indignation, collective action, and international citizenship (New York : United Nations University Press, 2000). 
${ }^{24}$ Figure cited in David P. Forsythe and Barbara Ann J. Rieffer, "US Foreign Policy and Enlarging the Democratic Community," Human Rights Quarterly 22 (Nov. 2000): 989.

${ }^{25}$ George W. Bush, "President Proposes \$5 Billion Plan to Help Developing Nations, March 14, 2002" available at the White House website at http://www.whitehouse.gov/news/releases/2002/03/20020314-7.html.

${ }^{26}$ Steven Radelet, “Bush and Foreign Aid,” Foreign Affairs 82 (Sept./Oct. 2003): 117.

${ }^{27}$ Originally offered as a sense of Congress resolution in 1974, the language was made binding in the International Security Assistance Act of 1978 (codified as amended at 22 USCS § 2304 [2004]).

${ }^{28}$ Numerous academic studies have shown the limited impact of the legislation. A recent example is Clair Apodaca and Michael Stohl, "United States Human Rights Policy and Foreign Assistance,” International Studies Quarterly 43 (March 1999): 185-198.

${ }^{29}$ Aryeh Neier, at the time executive director of Human Rights Watch, in Carroll J. Doherty, “Human Rights," The Congressional Quarterly Weekly Report, 5 December 1992, 3755.

${ }^{30}$ For more on these groups' work and mounting power, see Miles A. Pomper, "The Religious Right's Foreign Policy Revival," CQ Weekly, 9 May 1998, 1209-10; and Miles A. Pomper, “Religious Right Flexes Muscles on Foreign Policy Matters," CQ Weekly, 13 July 2002, 189396.

${ }^{31}$ Human Rights Watch, "U.S. Report on Religious Freedom is Flawed," 26 October 2001, available at http://www.hrw.org/press/2001/10/religious1026.htm.

32 Executive Order No. 13107, as quoted in Sean D. Murphy, "Contemporary Practice of the United States Relating to International Law," American Journal of International Law 93 (April 1999): 479.

${ }^{33}$ U.S. Human Rights Policy: A 20-Year Assessment, (United States Institute of Peace, June 16, 1999), 8 . 
${ }^{34}$ Patrick Flood, "Human Rights, UN Institutions, and the United States” in David P. Forsythe, ed., The United States and Human Rights: Looking Inward and Outward, (Lincoln: University of Nebraska Press, 2000): 367.

${ }^{35}$ Henry J. Steiner and Philip Alston, International Human Rights in Context: Law, Politics, and Morals: Text and Materials $2^{\text {nd }}$ edition (Oxford: Oxford University Press, 2000), 1144-1156.

${ }^{36}$ Meghan L. O’Sullivan, “Sanctioning 'Rogue States'," Harvard International Review 22 (Summer 2000): 56-60.

${ }^{37}$ Moore, "Globalization and the Future."

${ }^{38}$ David M. Lampton, “America's China Policy in the Age of the Finance Minister: Clinton Ends Linkage,” The China Quarterly 139 (Sept. 1994):597-621; Joseph Fewsmith, “America and China: Back from the Brink," Current History 93 (Sept. 1994): 250-255; John W. Dietrich, "Interest Groups and Foreign Policy: Clinton and the China MFN Debates," Presidential Studies Quarterly, 39 (June 1999): 280-96.

${ }^{39}$ Robert Kagan, "Power and Weakness," Policy Review 113 (Jun/Jul 2002), 3.

${ }^{40}$ Figure cited in Miles A. Pomper, “GOP Drive to Roll Back Sanctions Promises to be Case-byCase Struggle,” CQ Weekly, 10 February 2001, 339.

${ }^{41}$ Gary Clyde Hufbauer and Jeffrey J. Schott, assisted by Kimberly Ann Elliott, Economic Sanctions Reconsidered: History and Current Policy (Washington, D.C.: Institute for International Economics, 1990); Robert A. Pape, "Why Economic Sanctions Do Not Work," International Security 22 (Fall 1997), 90-136; and Kimberly Ann Elliot, “The Sanction's Glass: Half Full or Completely Empty?” International Security 23 (Summer 1998), 50-65.

${ }^{42}$ See Barbara Crossette, "For the First Time, U.S. Is Excluded From U.N. Human Rights Panel," The New York Times, 4 May 2001; and Christopher Marquis, "Washington Angry Over Losing Rights Seat,” The New York Times, 4 May 2001.

${ }^{43}$ Nina Shea, Director of the Center for Religious Freedom, Freedom House, "The UN Commission on Human Rights: A Review of Its Mission, Operations, and History,” Testimony 
before the House International Relations Committee's Subcommittee on International Operations and Human Rights, 6 June 2001, Federal News Service, Inc.

${ }^{44}$ Stephen D. Krasner, "Sovereignty,” Foreign Policy 122 (Jan/Feb 2001): 20-26.

${ }^{45}$ William A. Schabas, "Spare the RUD or Spoil the Treaty," in Forsythe, The United States and Human Rights, 110-25.

46 “Consideration of Reports Submitted by State Parties under Article 40 of the Covenant, Comments of the Human Rights Committee," quoted in Schabas, 111.

${ }^{47}$ Louis Henkin, “U.S. Ratification of Human Rights Conventions: The Ghost of Senator Bricker,” American Journal of International Law 89 (April 1995): 346-350.

${ }^{48}$ Senator John Bricker, quoted in Henkin, "U.S. Ratification,” 349.

${ }^{49}$ Kenneth Roth, "Sidelined on Human Rights," Foreign Affairs 77 (March/April 1998): 2-6.

${ }^{50}$ David J. Scheffer, "Staying the Course with the International Court," Cornell International Law Journal 35 (Nov. 2001): 47-98; and John R. Bolton, “The Risks and Weaknesses of the International Criminal Court from America's Perspective," Virginia Journal of International Law 41 (Fall 2000): 186-203.

${ }^{51}$ Diane Orentlicher, "Unilateral Multilateralism: United States Policy Toward the International Criminal Court," Cornell International Law Journal, 36 (2004): 419.

52 Scheffer, "Staying the Course," 73-4.

${ }^{53}$ Robert Tucker, "The International Criminal Court Controversy," World Policy Journal 18 (Summer 2001): 75-77.

${ }^{54}$ Bill Clinton, “The Right Action,” New York Times, 1 January 2001.

55 John R. Bolton, “The United State and the International Criminal Court,” remarks to the Federalist Society, 14 November 2002, available at the Department of State website at http://www.state.gov/t/us/rm/15158pf.htm.

56“The Melian Dialogue," in History of the Peloponnesian War by Thucydides, (New York: Penguin Books, 1954): 402. 
${ }^{57}$ Brinkley “Democratic Enlargement," 118, 125.

${ }^{58}$ Aryeh Neier, “The New Double Standard,” Foreign Policy 105 (Winter 1996/97): 91-101.

${ }^{59}$ U.S. Department of State, "Malaysia," Country Reports on Human Rights Practice- 2001, available at the Department of State website at http://www.state.gov.

${ }^{60}$ Michael Wines, "Road to U.S.-Russia Alliance Is Still Unmapped," New York Times, 21 October 2001.

${ }^{61}$ Sean D. Murhpy, "Decision not to regard persons detained in Afghanistan as POWs," The American Journal of International Law 96 (April 2002): 475-480.

62 Thom Shanker and Katherine Q. Seelye, “Captives: Behind-the-Scenes Clash Led Bush to Reverse Himself on Applying Geneva Conventions," New York Times, 22 February 2002.

${ }^{63}$ Ruth Wedgewood, “Al Qaeda, Terrorism, and Military Commissions," The American Journal of International Law 96 (April 2002): 328-35; George H Aldrich, “The Taliban, Al Qaeda, and the Determination of Illegal Combatants," The American Journal of International Law 96 (Oct. 2002): 891-898.

${ }^{64}$ Quoted in Dana Priest and R. Jeffrey Smith, "Memo Offered Justifications for Use of Torture; Justice Department Gave Advice in 2002,’ Washington Post, 8 June 2004.

${ }^{65}$ Dana Priest and Bradley Graham, "U.S. Struggled Over How Far to Push Tactics; Documents Show Back-and Forth on Interrogation Policy," Washington Post, 24 June 2004.

${ }^{66}$ In 1994, the Bureau's name was changed from Human Rights and Humanitarian Affairs to Democracy, Human Rights, and Labor.

${ }^{67}$ This and other observations are based on numerous interviews the author has conducted with officials in various State Department bureaus and the NGO community.

${ }^{68}$ Forsythe, "Human Rights in U.S. Foreign Policy: Retrospect and Prospect," 449.

${ }^{69}$ See the comments of several human rights leaders, in David Rieff, "The Precarious Triumph of Human Rights,” The New York Times Magazine, 8 August 1999. 
${ }^{70}$ Chicago Council of Foreign Relations, Foreign Policy Leadership Project, and Times-Mirror

Center for the People and the Press polls discussed in Ole Holsti, "Public Opinion on Human

Rights in American Foreign Policy," in Forsythe, The United States and Human Rights, 13174. 